During Brown's fifteen years' tenure of the Wilde readership, several attempts were again made in this direction; but, though encouraged by much friendly sympathy on the part of the authorities, the same lack of funds and rooms in which to house a laboratory made it impracticable. Last year, however, a generous offer of $£ 10,000$ was made through the Wilde reader for this purpose; and it was gladly accepted by the University. The curators of the University Chest will provide the necessary accommodation; and a further sum of $£ 500$, together with a grant of $£ 150$ a year for five years from the Rockefeller benefaction for research in the social sciences, is to go to the Institute.

\title{
Centenary of Darwin's Visit to the Galapagos Islands
}

\section{Issue of Commemorative Stamps by Ecuador}

$\mathrm{D}^{\mathrm{IS}}$ ISTINGUISHED men of science have, before now, been commemorated on postage stamps by countries sufficiently civilized to value their achievements, but it does not appear that any particular event in the history of science has hitherto been celebrated in this way. It has been left to the Republic of Ecuador to mark, by the issue of a special series of stamps, the centenary of a critical point in the development of the evolution theory. It was on September 16, 1835, that Darwin first landed on Chatham Island in the Galapagos group, where, as he wrote in his "Journal of Researches", "we seem to be brought somewhat near to that great fact-that mystery of mysteries-the first appearance of new beings on this earth". The influence of what he saw there on the later development of his thought is now a commonplace of biological teaching, although some modern writers on evolution might be well advised to read again his own account of his observations and the conclusions to which he was led.

The six stamps which are here reproduced bear designs associated with the islands or with Darwin's visit, the introduction of a portrait of Christopher
Columbus being apparently suggested by the Ecuadorean name for the group, "Archipelago of Colon". The portrait of Darwin is taken from a well-known photograph now hanging in Down

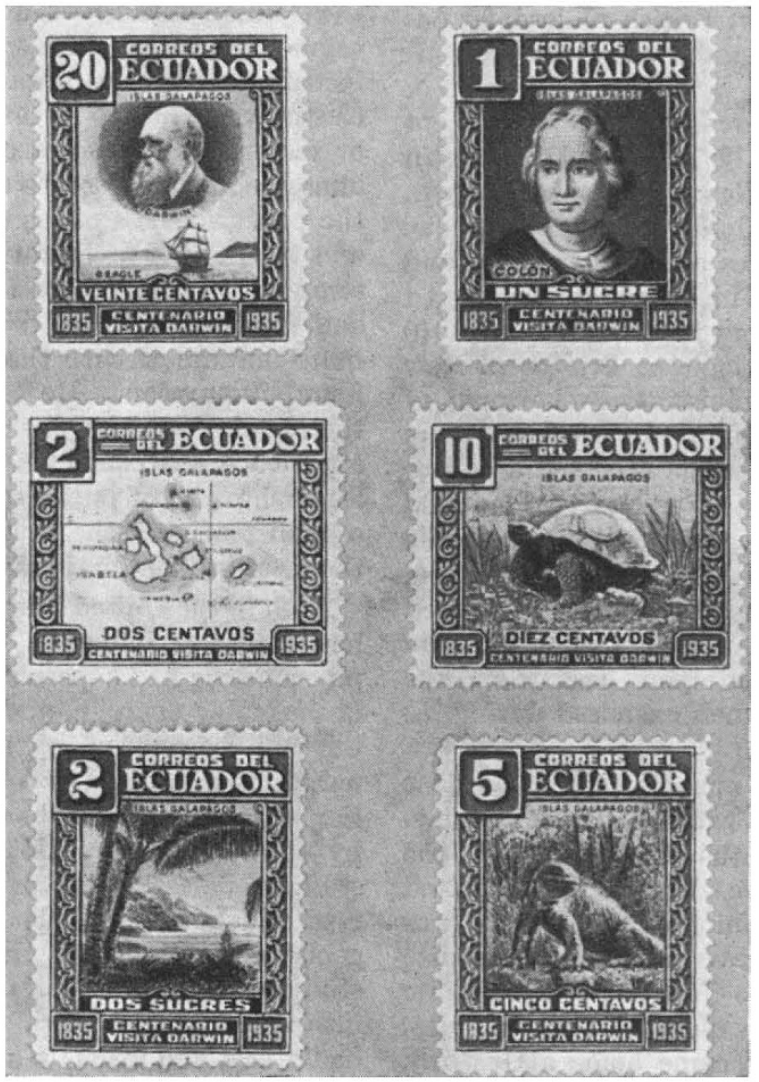
memoration of the centenary of Darwin's visit to the Galapagos Islands in the Beagle in 1835 .
Fra. 1. Stamps issued by the Ecuadorean Government in com-

House ; it represents him in his old age, and is probably that by which he is best remembered, although at the time of his visit to the Galapagos Islands he was, of course, a young man of twentysix years. A view, presumably representing some place in the islands, has a group of coconut palms in the foreground. If this is correct, it indicates a change in the flora since Darwin's time, for he notes in his "Journal", "I saw nowhere any member of the palm family". Two of the designs represent reptiles characteristic of the islands, one of the land iguanas and one of the giant tortoises from which the group takes its name. How many zoologists, one wonders, associate "Galapagos" with the familiar but etymologically obscure word "carapace"?

It is important to remember that one of the things that struck Darwin on visiting the islands was the abundance of individuals, especially of some of the larger reptiles. This density of 
population has now become a thing of the past, and the accounts of recent travellers make it clear that unless adequate protection can be given, the disappearance of this unique fauna is only a matter of time. It is therefore a subject for congratulation that the Ecuadorean Government has taken an enlightened view of its responsibilities. It has declared the greater part of the archipelago a Nature reserve, in which no hunting or collecting is allowed except by special permission for scientific purposes. Further, a list has been drawn up of the species more immediately threatened, and the killing or capture of these is prohibited, except that the inhabitants may kill some of them for food.

Many scientific bodies on both sides of the Atlantic have expressed their approval of the steps taken, and have offered to co-operate in rendering them effective. A committee of the British Association, under the chairmanship of Sir Edward Poulton, is at present considering what can be done to organise this international cooperation with the Ecuadorean Government.

W. T. Calman.

\section{Obituary}

\section{Prof. A. A. Bowman}

$\mathrm{B}^{\mathrm{x}}$ $Y$ the death on June 12 of Prof. A. A. Bowman at his home in Glasgow, British philosophy has lost one of its most effective and attractive personalities.

Prof. Bowman was fifty-three years of age. Except for the period of the War, he had spent his life in the study and teaching of philosophy, first in Glasgow, then in the United States, finally again in Glasgow. $\mathrm{He}$ took his degree in classics and philosophy : and after a post-graduate year in Germany, he served his apprenticeship to teaching in Glasgow. In 1910 he was elected professor of logic at Princeton, New Jersey, becoming later administrative chairman of the Department of Philosophy. In 1926, at more than a little material sacrifice, he accepted a call to return to his old University. For one year he held the chair of logic : and from 1927 until his death the chair of moral philosophy. At no time in the long history of that illustrious chair has its holder exercised a stronger personal influence upon his students, upon the University as a whole, and upon Glasgow and the west of Scotland, than Bowman exercised during his short tenure.

Bowman was profoundly a man of peace, and ardent in service of its better organization. The War, however, especially the last months of it, was one of the decisive experiences of his life. He was in the United States. But from the beginning of the War he was restless. In 1915 Princeton gave him leave of absence. The British authorities in the United States, thinking him (quite rightly) medically unfit for active service, refused to recruit him. He came home at his own expense, found some complaisant medical officer to pass him for home service, then, being in the army, badgered his superiors until finally they let him go to France. After a fow months campaigning, he was captured in the Lys break-through of April 1918 and sent to a prison camp. That, which seemed to be the end of his service, proved in fact to be his opportunity. Conditions in the camp were deplorable. Bowman's fluency in German made him the natural centre and unofficial leader of the camp. With tremendous resolution, he threw himself into the task first of improving those conditions through negotiation with the German authorities, and then of raising and maintaining the morale of his fellow prisoners. His main instrument for that purpose was a system of tutorial classes which had to be carried through without books or material or facilities of any kind; indeed, with almost no other resource than his own erudition and the persuasiveness of his teaching. He gave lectures and instruction in literature, in philosophy, in contemporary history (especially German and Russian), and in the history of art; and on groups of men quite unfamiliar with these themes, he made a profound impression. He taught them really to save their souls; and he was inspired in the task. That experience sharpened and developed his powers of leadership and of public speech. He had always been a good teacher; the prison camp made him one of the most brilliant and powerful expositors of his time.

Both in the United States and in Scotland Bowman had immense influence. Of slight and even frail physique, he had superb spiritual energy and insight, unshakeable courage, and, as has been noted, quite unusual powers of expression. Scholarship was natural to him : and although his flair was for specula. tion at once bold and thorough, it was always backed by solid learning. All his life he was an ardent student of classical and of modern literature. He had read widely in social theory and history. He was a good critic of painting. Especially in later years, his studies in the philosophy of religion had drawn him into the field of cultural anthropology, in which he had a vast and intimate knowledge of a great variety of primitive civilizations. All this equipment he brought into fullest play in the ordinary business of his crowded class-room. His students, indeed any audience which he addressed, fell instantly under his spell. For his learning, his humour and his eloquence were no more than the instruments of a man of richest personal quality - of deep insight, of rare imaginative power, and of profound moral and social convictions. In philosophy, he held by the Idealist tradition in which he had been nurtured. He gave it 